\title{
A Case of an Interstitial Deletion in Chromosome 1p Confirmed by Array Comparative Genome Hybridization
}

\author{
Mi Jung Park ${ }^{1}$, Shin-Hye Kim ${ }^{1}$, Dong-Ju Lim², and Soo Jin Yoo ${ }^{3}$ \\ Departments of 1 Pediatrics, 2 Orthopedic Surgery, and ${ }^{3}$ Laboratory Medicine, Inje University Sanggye Paik Hospital, Inje University \\ College of Medicine, Seoul, Korea
}

\section{Corresponding author:}

Soo Jin Yoo

Department of Laboratory Medicine, Inje University Sanggye Paik Hospital, Inje University College of Medicine, 1342 Dongil-ro, Nowon-gu, Seoul 01757, Korea

Tel +82-2-950-1242

Fax +82-2-950-1244

E-mail sjyoo@paik.ac.kr

Received: August 27, 2020

Revised: September 22, 2020

Accepted: September 24, 2020

This is an Open Access article distributed under the terms of the Creative Commons Attribution Non-Commercial License (http://creativecommons.org/licenses/ by-nc/4.0) which permits unrestricted non-commercial use, distribution, and reproduction in any medium, provided the original work is properly cited.
Deletion in chromosome $1 \mathrm{p}$ is a rare chromosomal abnormality, and its genotype-phenotype correlation has not yet been clearly determined. Here, we report the molecular cytogenetic findings and clinical manifestations observed in a patient with an interstitial deletion in the short arm of chromosome 1 . The patient was a 12-year-old boy who presented with short stature, intellectual disability, and scoliosis. Array comparative genomic hybridization analysis of peripheral blood revealed a deletion of $6.5 \mathrm{Mb}$ at $1 p 31.1 p 31.3$. We investigated the genotype-phenotype relationship of $1 p$ deletion based on this and previously reported cases. Deletion of the NEGR1 gene was regarded the causative rearrangement in terms of patients' intellectual disability and scoliosis. In addition, deletion of the $L R R C 7$, GADD45, RPE65, and CTH genes are also candidates for involvement in developmental delay in chromosome 1p deletion.

(Lab Med Qual Assur 2020;42:224-228)

Key Words Deletion, Chromosome 1, Comparative genomic hybridization

\section{증례}

12 세 남아가 작은 키와 성장 부전으로 성장클리닉을 내원하였 다. 아이는 임신 나이 37 주, 출생 체중 $2.3 \mathrm{~kg}$ 에 정상 질식 분만으 로 태어났으며, 임신기간과 출생 후 별다른 문제는 없었다고 하였 다. 정상 표현형을 보이는 부모의 두 번째 아이였으며, 저신장이나 발달지연의 가족력은 없었다. 출생 이후 따라잡기 성장이 되지 않 아 만 4세에 성장클리닉에 내원한 과거력이 있으며, 키는 2.5 백분 위수, 체중 0.7 백분위수, 머리둘레가 3 백분위수 미만이었다.

12 세에 다시 내원했을 때 키는 20 백분위수, 체중 6.2 백분위 수, 체질량지수 5.4 백분위수였다. 지적장애 3 급 경계범위의 지적 수준을 보였고, 발작의 과거력은 없었다. 왼쪽 얼굴이 오른쪽보다 상대적으로 덜 발달된 안면 비대칭 소견을 보였고, 고 아치형 구개 (high arched palate), 불규칙한 치열을 보였다. 경도의 오목가슴
이 관찰되었으며, 척추 X선 검사에서 콥스(Cobb's) 각도 $17^{\circ}$ 의 요 추부 측만증과 이에 보상적으로 발생한 만곡각 $11^{\circ}$ 의 흉추부 측만 증을 보였으며, $1.5 \mathrm{~cm}$ 정도의 몸통 중심 이동(trunk shift)이 동 반되어 있었다. 고환과 음모 발달은 성성숙도 태너 3단계의 정상 사춘기 발달을 보였다. 혈청 테스토스테론 $3.8 \mathrm{ng} / \mathrm{mL}$ (참고범위, 0.649-7.78), 황체형성호르몬 $1.84 \mathrm{mIU} / \mathrm{mL}$ (참고범위, 0.1-6.0), 인슐린유사성장인자-1 $447.1 \mathrm{ng} / \mathrm{mL}$ (참고범위, 188.4-509.9), 갑상샘자극호르몬 $1.060 \mu \mathrm{lU} / \mathrm{mL}$ (참고범위, 0.55-4.78 $\mu \mathrm{lU} / \mathrm{mL}$ ) 로 확인되었다.

염색체 미세결실 질환을 의심하여 array comparative genomic hybridization (aCGH)를 시행하였다. $1 \mathrm{Mb}$ 간격의 해 상도를 보이는 SurePrint G3 Human CGH $1 \times 1$ M Microarray (Agilent Inc., Santa Clara, CA, USA)를 사용하였고, 연속된 3개 이상의 소식자에서 정상인의 DNA와 비교하여 정상화된 $\log 2$ 비 
율이 0.25 초과일 경우 증폭으로, -0.25 미만일 경우 소실로 판단 하였다. Copy number variants (CNV)는 DECIPHER database (http://decipher.sanger.ac.uk)와 USCS Genome Browser (http://www.genome.ucsc.edu/cgi-bin/hgGateway)의 공개 된 데이터베이스를 통해 분석하였다. $\mathrm{aCGH}$ 검사에서 $1 \mathrm{p} 31.1-$ p31.3에 6,474 Kb의 소실이 확인되었다(Fig. 1).

말초혈액 검체를 phytohaemagglutinin를 첨가한 RPMI 배 지에 넣고 3일간 배양 후 G-분염법으로 핵형을 분석하였다(Fig. 2). 핵형분석 사진과 $\mathrm{aCGH}$ 를 종합한 결과, ISCN (International System for Human Cytogenetic Nomenclature) 2019 명 명법에 준해 46,XY,del(1)(p31.1p31.3).arr[GRCh37]1p31. 3p31.1(67902093_74376253) $\times 1$ 로 기술하였다[1]. 부모의 말

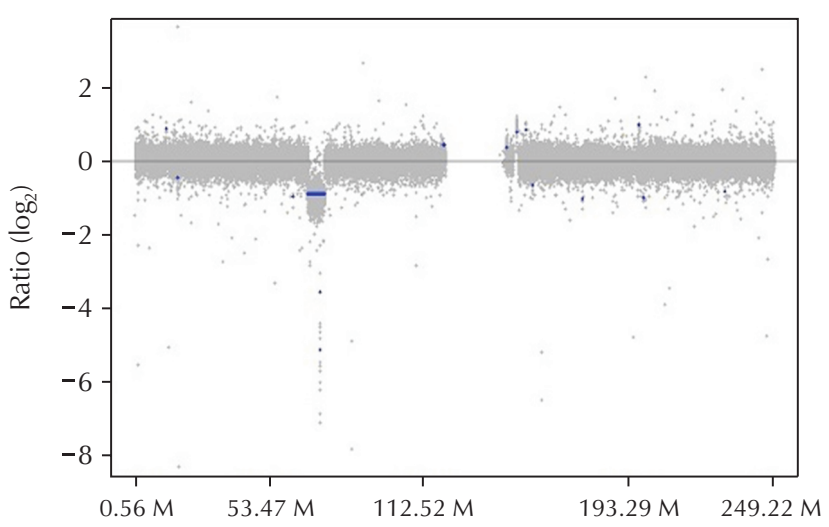

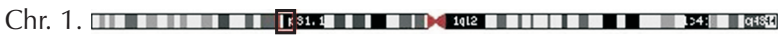

Fig. 1. Array comparative genomic hybridization analysis of the peripheral blood indicating a loss of $6.5 \mathrm{Mb}$ in chromosome 1 . The $y$-axis represents the log2 of the intensity ratios of patient/control DNA. The $x$-axis represents the distance from the $1 p$ telomere of the BAC clones.
초혈액 염색체검사를 권고하였으나, 검체를 확보하지 못하여 검사 를 수행할 수 없었다.

\section{고찰}

저자들은 $\mathrm{aCGH}$ 를 통해 확인된 1 번 염색체 단완의 $6.5 \mathrm{Mb}$ 크기 의 염색체내결실의 증례에서 유전학적 소견과 표현형을 보고하고, 이전에 유사한 부위의 결실로 보고된 증례와 비교하여 비정상 표 현형의 원인이 되는 후보 유전자와 이의 표현형과의 관계를 기술 하고자 한다.

1 번 염색체 단완의 염색체내결실은 드물고 그 결실부위도 다양 하다[2]. $\mathrm{aCGH}$ 와 같은 분자세포유전학적 기법이 보편화되기 전 에 발표된 증례들은 절단점을 정확히 파악하기 어려워 유전형-표 현형 관계를 분석하는 데 한계가 있다[3-5]. 본 증례와 세포유전학 적으로 유사한 절단점을 보이는 결실이 3예가 보고되었다[3,4,6]. 이들은 1번 p22-p31.3 사이의 결실로 보고되었고, 핵형 사진상 본 증례와 유사했고, 표현형적으로는 중등도의 정신지체, 소두증, 좁은 얼굴, 치아 형성 부전 등이 공통소견이었다.

$\mathrm{aCGH}$ 를 통해 절단점까지 규명한 $1 \mathrm{p}$ 염색체내결실 증례도 표 현형 기술이 자세하지 않아 아직 유전형-표현형 관계가 명확하 지 않다[2,6-10]. 이 중 결실부위가 본 증례와 비교할만한 증례들 을 비교분석하였다(Table 1). 본 증례와 절단점이 가장 유사한 증 례는 Tassano 등[2]과 Gillberg와 FitzPatrick [10]이 보고한 1 번 단완의 6.3-6.5 Mb 결실의 두 증례였다. 모두 인지 및 학습장 애, 언어장애를 보고하였으나, 얼굴과 근골격계 이상은 서로 차이 를 보였다. 그 외 Table 1 에 기술한 여러 증례에서 인지, 지능장애 와 함께 주의력결핍장애, 언어장애 등을 보고하였다. 우리 환아에 서 관찰된 척추측만증은 일부에서만 기술되었고[7], 경도의 오목 가슴, 척추후만증이 각 한 예에서 보고되었다[10].
A

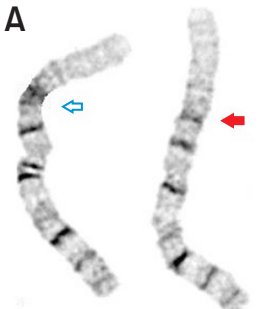

A-1

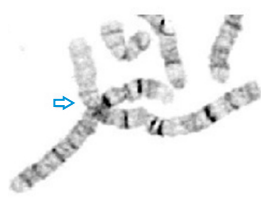

B

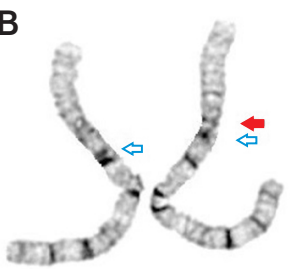

B-1

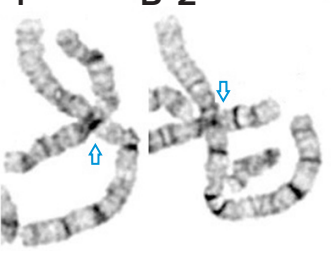

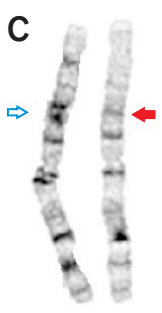

C-1

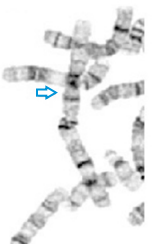

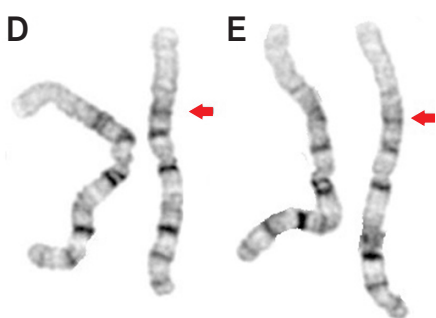

Fig. 2. Partial GTG-banded karyogram $(A, B, C, D, E)$ of the patient indicating del(1)(p31.1p31.3). The filled arrows indicate the shortened $1 p 31$ bands on the right side of each pair of chromosome 1 . The partial images of metaphase cell spreading showing chromosome 1 of the upper image for each corresponding number (A-1, B-1, B-2, $C-1)$. The hollow arrows indicate that the short arms of chromosome 1 crossover with other chromosomes. 


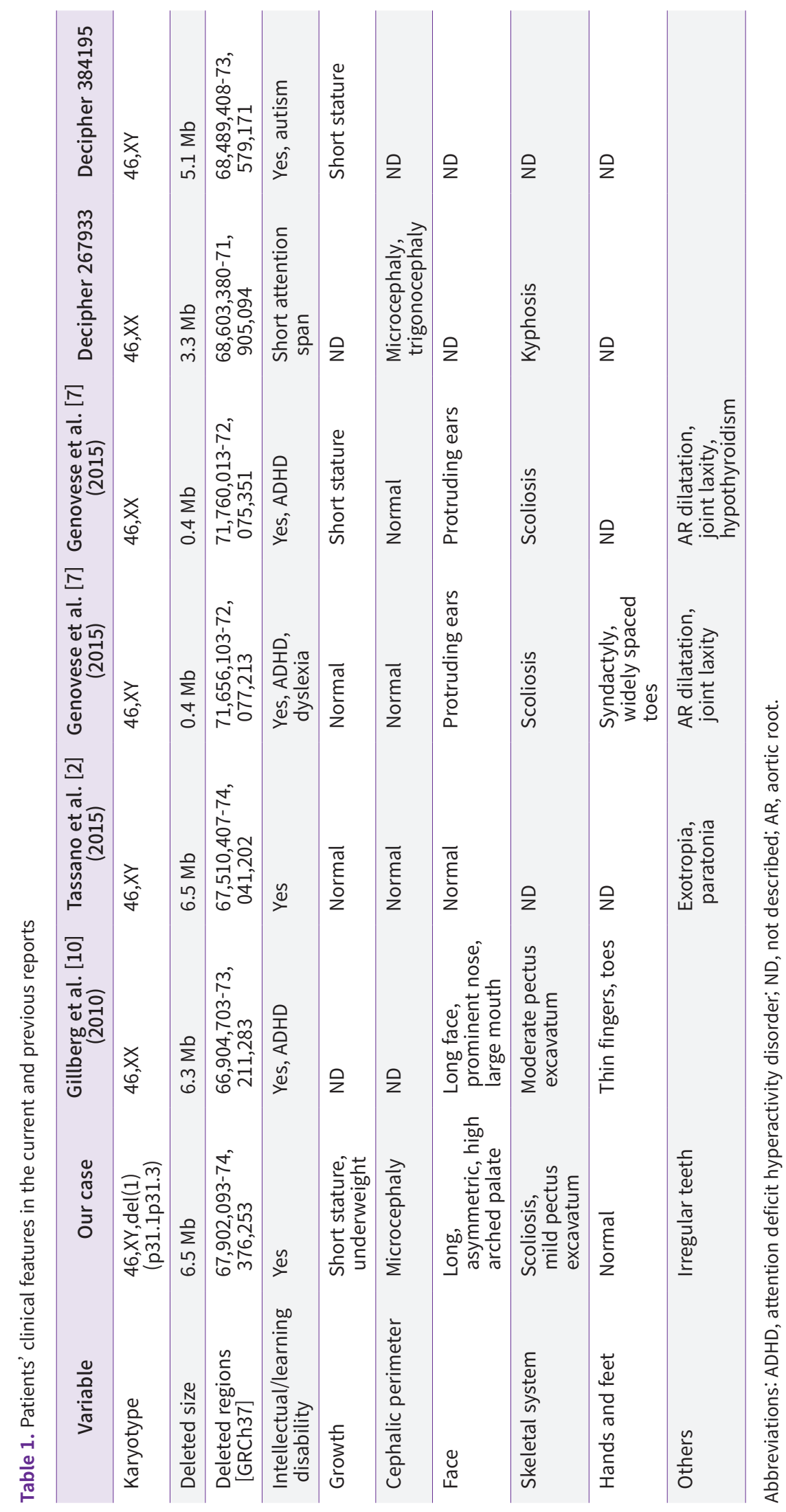


1 번 단완 결실 환자에서 인지 및 언어발달의 원인 후보 유전 자로 Tassano 등[2]은 LRRC7, GADD45, NEGR1 유전자를 지 목하였다. LRRC7 유전자(MIM 614453; leucine-rich repeatcontaining protein 7)는 뇌특이세포 내 막결합단백을 만드는데, 시냅스 후 치밀질에 고농도로 분포하며 세포부착, 수지분지, 신경 세포흥분에 관여한다. 동물실험에서는 $L R R C 7$ null mutation이 정신질환의 행동이상, 인지장애 등과 관련되었다[11]. GADD45A 유전자(MIM 126335; growth arrest-and DNA damageinducible gene) 산물은 작은 핵 내부단백으로 메칠화 조절인자 로 뇌피질 등 신경의 분화, 발달에 관여한다[2,12].

Gillberg와 FitzPatrick [10]은 66,904,703-73,211,283에 서 4.9-6.3 $\mathrm{Mb}$ 의 결실을 보고하였고, 인지, 언어, 학습장애와 심한 운동발달장애와 주의력결핍장애, 얼굴 형태이상, 오목가 슴 등을 보인 증례에서 IL23R, RPE65, CTH 유전자의 원인 가능 성을 언급하였으나, 이전 보고들과 비교하여 유전형-표현형 연 관성을 찾을 수 없다고 보고하였다. 본 증례에서는 IL23R 유전 자가 결실되지 않았다는 차이가 있다. 이 연구에서 보고된 환아 의 사진 등을 고려할 때 얼굴 모양, 경도의 오목가슴 등의 공통 소견을 보여 두 증례에서 공통적으로 결실을 보인 RPE65, CTH, $N E G R 1$ 등이 관찰된 표현형에 영향을 보였을 가능성을 추측해 볼 수 있겠다. RPE65 유전자(MIM 180069)는 Leber congenital amaurosis, retinitis pigmentosa 질환과의 관련성만 알려져 있 다. CTH 유전자(MIM 607657)는 임상적으로 cystathioninuria, hyperhomocysteinemia 등과 연관된 유전자이다.

본 증례와 앞서 언급한 Tassano 등[2]과 Gillberg와 FitzPatrick [10]이 보고한 증례 모두 NEGR1 유전자의 결실을 보 인다. Genovese 등[7]은 $1 \mathrm{p} 31.1$ 부위에서 $400 \mathrm{~K}$ 정도의 미세 결실로 단백질코딩 유전자 중 NEGR1 유전자만 결실을 갖는 가 계를 보고했는데, 남매에서 지능저하와 척추측만증, 대동맥뿌 리확장, 관절이완증을 공통적인 소견으로 보였다. 학습 및 인지 장애, 척추측만증은 본 증례와 공통적인 소견으로 NEGR1 유전 자가 이런 표현형의 원인일 가능성을 시사했다. NEGR1 (MIM 613173; neuronal growth regulator 1) 유전자는 1번 염색 체 71.868.625-72.748.533 (CRCH37, hg19) 부위에 존재하며, NEGR1 단백은 세포부착물질으로 신경의 성장, 분열, 분화에 관여 하고, 주로 축삭의 시냅스 전부위에 발현해 신경세포의 돌기형성, 시냅스 전달에 관여한다 $[2,7,13,14]$. DECIPHER 데이터베이스 에 NEGR1 유전자 결실이 보고된 3예(DECIPHER no., 280382, 289632, 287447; http://decipher.sanger.ac.uk) 및 Tassano 등[2], Genovese 등[7]이 보고한 증례에서도 언어발달장애, 인지 장애 등이 공통적인 소견으로 보고되었다. 이전에도 10 가계의 연 구를 통해 NEGR1 유전자의 de novo CNV와 읽기장애의 연관성
과 신경학적 이상(비정상 근육긴장, 사시 등), 중추신경계 비정상 소견(소두증, 뇌기형 등)과의 관련성도 제시되었다[7].

언급한 증례들을 종합할 때 $L R R C 7$, GADD45, NEGR1, RPE65, $\mathrm{CTH}$ 등의 유전자가 인지장애, 언어장애 등을 초래했을 가능성이 높고, 특히 모든 증례에서 결실이 관찰된 NEGR1 유전자의 역할이 주목된다. 그러나 공통적인 결실을 보인 증례에서 얼굴 및 근골격 계 이상소견은 차이가 많아 본 증례의 척추측만증 등의 소견이 어 떤 유전자 결실과 관련되었는지 단정하기는 어려웠다.

본 증례와 유사한 6.3-6.5 Mb의 결실을 보인 Tassano 등[2]과 Gillberg와 FitzPatrick [10]이 보고한 증례들은 정상 핵형을 보 였다고 보고하였고 핵형 사진은 제시하지 않았다. 그러나 본 증례 에서는 임상상과 $\mathrm{aCGH}$ 결과를 확인한 후 핵형분석 사진을 판독 한 결과, 1p31.1-p31.3 밴드의 결실을 확인할 수 있었다. 그러나 핵형분석한 일부 세포에서는 정상 또는 비정상 1 번 염색체가 다른 염색체와 중첩되어 모든 밴드를 정확히 분석할 수 없었다. 그러나 다른 세포를 추가로 분석했을 때 1 번 단완의 결실을 확인할 수 있 었다. 1 번 염색체는 가장 긴 염색체로 분열중기세포의 상태를 현 미경으로 분석하면 다른 염색체와 중첩된 것을 흔히 볼 수 있다. 이렇게 중첩이 있는 세포만 분석할 경우 모든 밴드를 관찰할 수 없 고, 구조적 이상을 파악하기 위해 상동염색체끼리 비교분석할 때 도 중첩으로 인해 정확한 비교가 어렵다. 따라서 1 번 염색체 및 기 타 긴 염색체의 중첩이 관찰될 경우 추가적으로 여러 세포를 분석 하여 모든 염색체 밴드를 충분히 분석할 수 있도록 유의해야겠다. 특히 전문의가 소수의 정상 핵형 사진만 판독할 경우 일부 수적, 구조적 이상을 발견하지 못할 수 있으므로 충분한 수의 핵형 분석 이미지를 검토할 필요가 있겠다. 또한 해상도를 최적의 상태로 관 리하고 가능한 고해상도의 세포를 분석하는 것도 중요하겠다. 본 증례를 통해 검사실 실정에 맞는 판독절차와 구조적 이상에 대한 면밀한 분석의 중요성을 다시 한번 강조할 수 있었다.

본 환아의 부모는 정상 표현형을 보였으나, 자녀에서 발생한 비 정상 염색체의 원인을 규명하고, 정확한 유전상담을 위해 부모의 말초혈액 염색체검사를 권유하였다. 그러나 부모가 유전자검사에 대해 동의하지 않아 검사를 실시하지 못하였고, de novo 발생 여 부를 염색체검사를 통해 확인하지는 못하였다.

저자들은 국내에서 처음으로 1번 염색체 단완 p13.1-p13.3 부 분의 염색체내결실을 확인하고 보고하는 바이다. 1 번 단완결실을 보인 본 환아는 인지장애, 척추측만증, 저신장 등의 표현형을 보였 다. NEGR1 유전자가 일부 표현형의 원인임을 확인할 수 있었고, LRRC7, GADD45, RPE65, CTH 유전자가 표현형에 미치는 영향 에 대한 추가 검토가 필요하다. 


\section{REFERENCES}

1. McGowan-Jordan J, Simons A, Schmid M. An International System for Human Cytogenetic Nomenclature 2016. Basel: Karger, 2016.

2. Tassano E, Gamucci A, Celle ME, Ronchetto P, Cuoco C, Gimelli G. Clinical and molecular cytogenetic characterization of a de novo interstitial 1p31.1p31.3 deletion in a boy with moderate intellectual disability and severe language impairment. Cytogenet Genome Res 2015;146:39-43.

3. Petersen MB, Warburg M. Interstitial deletion 1p in a 30 year old woman. J Med Genet 1987;24:229-31.

4. Lai MM, Robards MF, Berry AC, Fear CN, Hart C. Two cases of interstitial deletion 1p. J Med Genet 1991;28:128-30.

5. Bene M, Duca-Marinescu A, Ioan D, Maximilian C. De novo interstitial deletion del(1)(p21p32). J Med Genet 1979;16:323-7.

6. Mircher C, Rethore MO, Lespinasse J, Fert-Ferrer S, Lundsteen C, Kirchoff M. Interstitial deletion of the short arm of chromosome 1: attempt to establish a clinical phenotype (46,XX,del (1)(p22p32)). Am J Med Genet A 2003;118A:176-9.

7. Genovese A, Cox DM, Butler MG. Partial deletion of chromosome 1p31.1 including only the neuronal growth regulator 1 gene in two siblings. J Pediatr Genet 2015;4:23-8.

8. Rivera-Pedroza Cl, Barraza-Garcia J, Paumard-Hernandez B, Nevado J, Orbea-Gallardo C, Sanchez Del Pozo J, et al. Chromosome 1p31.1p31.3 deletion in a patient with craniosynostosis, central nervous system and renal malformation: case report and review of the literature. Mol Syndromol 2017;8:30-5.

9. Petti M, Samanich J, Pan Q, Huang CK, Reinmund J, Farooqi S, et al. Molecular characterization of an interstitial deletion of $1 \mathrm{p} 31.3$ in a patient with obesity and psychiatric illness and a review of the literature. Am J Med Genet A 2011;155A:825-32.

10. Gillberg C, FitzPatrick D. Case report: further evidence for a recognizable syndrome caused by deletion of $1 p 31$. Adv Clin Neurosci Rehabil 2010;3:16-8.

11. Carlisle HJ, Luong TN, Medina-Marino A, Schenker L, Khorosheva E, Indersmitten T, et al. Deletion of densin-180 results in abnormal behaviors associated with mental illness and reduces mGluR5 and DISC1 in the postsynaptic density fraction. J Neurosci 2011;31:16194-207.

12. Sarkisian MR, Siebzehnrubl D. Abnormal levels of Gadd45alpha in developing neocortex impair neurite outgrowth. PLoS One 2012;7:e44207.

13. Veerappa AM, Saldanha M, Padakannaya P, Ramachandra NB. Family-based genome-wide copy number scan identifies five new genes of dyslexia involved in dendritic spinal plasticity. J Hum Genet 2013;58:539-47.

14. Wheeler E, Huang N, Bochukova EG, Keogh JM, Lindsay S, Garg S, et al. Genome-wide SNP and CNV analysis identifies common and low-frequency variants associated with severe early-onset obesity. Nat Genet 2013;45:513-7. 